\title{
FACTORS GOVERNING THE FAT CONTENT OF BAC- TERIA AND THE INFLUENCE OF FAT ON PELLICLE FORMATION *
}

\author{
L. W. LARSON AND W. P. LARSON
}

From the Department of Bacteriology and Immunology, University of Minnesata, Minneapolis

This paper deals with the acetone, petrol ether and ether extracts of various organisms grown with different substances as sources of carbon.

The study of the fat content of plant and animal cells is a most difficult problem. In the case of bacterial cells this is particularly true; first, because of the difficulty in obtaining large quantities with which to work; and second, because of difficulties in extracting the pure fats from any medium which contains water. The latter becomes a serious obstacle in the fat extraction of bacteria because there is no satisfactory methor of drying the organisms without changing the structure and chemical constituents of the cell. For this reason this work was conducted by using acetone which would serve both as a dehydrant and a fat extractive and would remove the obvious objections to dehydrating the organisms by means of heat, sulphuric acid, alcohol, etc. The results obtained cannot be proved to represent an absolue criterion of the fat content for each organism since acetone and ether will extract stubstances other than fats, but in each case the results are comparable to those of every other case, because of the uniformity of medium, the time allowed for growth of the organisms, and the similar method of extraction.

One of the greatest obstacles confronting earlier workers on the analysis of bacterial cells was the difficulty in obtaining large enough quantities of the organisms with which to work. Centrifuges suitable for this type of work were almost unused up to the last decade, and the primitive and laborious method of scraping the growth from agar plates or skimming it from liquid mediums prevailed. For this reason the work on bacterial cell analysis is comparatively meager and restricted to certain types of bacteria. The tubercle bacillus has been most extensively studied probably because of its abundant growth on glycerol broth.

Received for publication, July 7, 1922.

* Aided by a Grant from the National Dental Research Association. 
Cramer, ${ }^{2}$ in 1893 , published his results on the composition of bacteria with respect to the character of the medium. He analyzed several organisms for carbon, oxygen, nitrogen, hydrogen, ash and fat content. His method of fat extraction was by means of the Soxhlet apparatus using alcohol and ether as solvents. This method necessarily gave extractives other than fats as alcohol dissolves out other substances. However, his results are of interest. He analyzed the Bacillus mucous capsulatus and Bacillus rhinoscleroma grown on $1 \%$ and $5 \%$ peptone with $5 \%$ dextrose. His results show about $10 \%$ fat for both organisms when grown on $1 \%$ and $5 \%$ peptone, and $20 \%$ (an increase of $100 \%$ ) when grown on $5 \%$ dextrose. He concludes that on easily assimilable medium the composition of the bodies of the same germ from different sources and which vary in virulence is about the same. Where, however, the medium supplies food that is assimilable with difficulty the composition of the bodies of the germs will vary. The comparison which he makes between these and several other species shows a variation which indicates a distinct and characteristic composition for each germ. He does not consider the action of the organism on the medium.

The preliminary work by Hammerschlag ${ }^{2}$ on the substances contained in the bodies of the tubercle bacillus which could be extracted with ether and alcohol, and the probable composition of the extract so obtained, furnished considerable material for speculation. He grew the tubercle bacillus on glycerol bouillon and on glycerol peptone agar and obtained the organisms by skimming the growth from the liquid medium or scrapping it from the agar. He then extracted the organisms with ether and alcohol and dried to constant weights. His results show 28 and $26 \%$ fat, respectively, from 2 different strains.

De Schweinitz and Dorset ${ }^{3}$ reported their results on the fat content of the tubercle and glanders bacilli. They grew large quantities of the organisms on glycerol beef broth and also on ordinary beef broth medium, freed the organisms by filtration and washed out all soluble products with water. The organisms were then dried over sulphuric acid and just before analysis were further dried by heating to $100 \mathrm{C}$. They state that by means of this drying process the organisms underwent no change in color. They then analyzed the dried organisms for nitrogen, carbon, oxygen, phosphorus, sulphur, ash, etc., and conclude that "with the exception of the nitrogen, there seems to be very little variation in the composition of the germs grown on beef broth or on ordinary media." Their article does not make direct mention of the fat content or just what procedures were followed. Their results show a total ether extract of the tubercle bacillus grown on beef broth averaging $39.29 \%$ to $40.8 \%$ but no alcoholic extract; on the artificial medium the ether extract was $37.57 \%$ to $38.54 \%$ and the alcoholic extract $4.44 \%$.

Subsequent work by Klebs, ${ }^{4}$ Weyl, ${ }^{5}$ Ruppel, ${ }^{6}$ Aronson, ${ }^{7}$ and Levene ${ }^{8}$ substantiated De Schweinitz and Dorset's conclusions that the tubercle bacillus contains from 27 to $38 \%$ fat, depending on the strain.

In 1902 De Schweinitz and Dorset ${ }^{3}$ reported further investigations on the tubercle bacillus. They grew the organisms on $7 \%$ glycerolated acid potassium

t Arch. f. Hyg,, 1893, 16, p. 151.

2 Centralbl. f, klin. Med., 1891, 12, p. 9.

8 Jour. Am. Chem. Soc., 1895, 17, p. 605.

4 Centralbl, f. Bakteriol., 1896, 20, p. 488.

5 Deutsch. med. Wchnschr., 1891, 17, p. 256.

a Ztschr. f. phys. Chemie, 1899, 26, p. 218.

7 Berl. klin. Wchnschr., 1898, 35, p. 484.

8 Jour. Med. Research, 1901, 6, p. 135.

a Centralbl. f. Bakteriol., 1902, 32, p. 186. 
phosphate broth, washed them with hot water to remove the phosphates, then dried over sulphuric acid, powdered and dried to constant weight at $60 \mathrm{C}$. in vacuo. Extractions were then made with hot ether, hot alcohol and hot chloroform. They obtained $26.32 \%$ total extracts from the bovine strain, $20.59 \%$ from the swine strain, $31.76 \%$ from the horse strain, $30.65 \%$ from the avian strain, $37.41 \%$ from the attentated human strain and $28.03 \%$ from the virulent human strain. They assume that the virulent human, horse, bovine ard avian strains produce less harmful fatty substances, and therefore a relatively greater amount of poisonous proteid material than the attenuated human strain, and that this might explain the differences in virulence. This is in disagreement with the work of Frouln ${ }^{10}$ who found the reverse to be the case. As will be pointed out later, they do not consider the action of the various strains on the glycerol contained in the medium.

Lyons $^{11}$ investigated the fat content of 3 organisms. We are unable to determine what micro-organisms he was working with, but it is obvious that the Pfeiffer bacillus he refers to is not the influenza bacillus as we know it today, as his organism was encapsulated and grew well on the routine mediuns. Another he designated as number 28 and a third as a threadlike bacillus. He grew these organisms on 1,5 and $10 \%$ dextrose agar, respectively, scraped the growth off, dried in a desiccator and ground to a fine powder. He then obtained ether-and alcohol extracts by means of a Saxhlet apparatus. $\mathrm{He}$ found that the alcohol extract increased as the amount of sugar in the medium was increased but that the ether extract increased only up to $5 \%$ sugar and decreased on addition of more sugar. The sum of the ether and alcohol extracts, however, increased with an increase of sugar in the medium. His method of using alcohol as a solvent is open to criticism for alcohol will dissolve out things other than fats. Hence we must conclude that his total alcohol and ether extracts represent an amount in excess of the exact amount of fat present in the organisms. Since he does not give the action of the organisms on sugar: and since his organisms are not well known today, his work does not contribute much to our knowledge of the fat content of bacteria.

Dawson ${ }^{12}$ studied the fat content of the colon bacillus grown on 8 different mediums. He treated weighed quantities of wet bacteria with $20 \%$ antiformin for 24 hours at $30 \mathrm{C}$; then heated to $60 \mathrm{C}$. for one hour. After cooling to $15 \mathrm{C}$. and neutralizing with $\mathrm{N} / 10$ sulphuric acid, the solution was evaporated to dryness at $80 \mathrm{C}$, ground and extracted with ethyl ether or petrol ether. The residue was slowly boiled in $10 \%$ sodium hydroxide and after boiling was rendered acid with dilute sulphuric acid. It was then diluted to 3 times the original volume with distilled water and cooled to 7 to $10 \mathrm{C}$. after which it was filtered. The precipitate was washed, dried and extracted with petrol ether for 5 hours. He obtained $3.99 \%$ fat when the organism was grown on $1 \%$ peptone plus $1 \%$ meat extract broth, $5.77 \%$ on glucose broth, and $8 \%$ on $1 \%$ glycerol glucose broth. These figures are comparable with ours, being somewhat smaller. No mention is made of the relation of the medium and the action of the organism on the medium to the fat content.

Froin's ${ }^{10}$ work on the fat content of the tubercle bacillus is of great interest. He found that the bovine (with one exception) and the avian strains had high fat contents, ranging from 42 to $54 \%$ when grown on glycerol mediun while the human strains have about one-half (19 to $21 \%$ ) as much fat as the bovine and avian strains. He adds that the effect of the glycerol is noteworthy, and

\footnotetext{
10 Compt. rend, Soc. de biol., 1921, 84, p. 606.

11 Arch. f. Hyg., 1897, 28, p. 30.

12 Jour. Bacteriol., 1919, 4, p. 133.
} 
the comparison of the fat and wax content in human and bovine bacilli grown under identical conditions suggests that this chemical factor may be associated with the virulence of the strains for laboratory animals.

The work here reported was inaugurated for the purpose of studying the relation of the fat content of bacteria to pellicle formation. Larson, Cantwell, and Hartzell ${ }^{13}$ have shown that pellicle formation may be suppressed by lowering the surface tension of the culture medium. Larson $^{14}$ ascribes this phenomenon to a condition of more complete wetting of the organism by the fluid. It is obvious that factors other than the surface tension of the medium enter into this phenomenon since not all bacteria form pellicles when grown on a medium of given surface tension.

On glycerol broth many organisms will grow with definite pellicle formation even though the surface tension of the glycerol broth is approximately that of ordinary broth. If pellicle formation is an indication of incomplete wetting of the bacteria, it follows that there must be differences in the ability of various bacteria to become wetted.

It seemed to us that differences in the amount and possibly the disposition of the fats of the cell might account for the difference in behavior of bacteria grown under identical conditions. The effect of glycerol and various carbohydrates on the fat content have been studied.

The technic used in this work was as follows: Pure strains of an organism were grown on plain broth, $0.5 \%$ dextrose broth and $3 \%$ glycerol broth, respectively. The broth contained $12 \mathrm{gm}$. of Liebig's beef extract, $20 \mathrm{gm}$. peptone and $10 \mathrm{gm}$. of sodium chloride to a liter of distilled water, and titrated to $1 \%$ acidity. The dextrose and glycerol broth were composed of plain broth plus $0.5 \%$ dextrose and $3 \%$ glycerol, respectively. The organisms were grown at $37 \mathrm{C}$. for 4 days and then centrifuged in a Sharpless centrifuge at 40,000 revolutions per minute. The organisms so obtained were washed several times in distilled water to remove the phosphates, and were then transferred to a beaker. Because of the high speed of the centrifuge the mass of organisms so obtained was wet but not watery, and the water present was held in the pores of the caseous mass. Redistilled acetone, boiling point at 57 to $60 \mathrm{C}$., was added to the cheeselike mass of bacteria as they were obtained from the centrifuge, and the mixture was stirred briskly and allowed to stand for from 3 to 5 days. The mixture was then transferred to large centrifuge tubes and centrifuged at high

13 Jour. Infect. Dis., 1919, 25, p. 41.

14 Proc. Soc. Exper. Biol. and Med., 1921, 19, p. 62. 
speed, the supernatant fluid decanted, more acetone added and the process of extraction by standing was continued until the organisms had been treated for from 10 to 14 days. Then the process was repeated with redistilled ethyl ether. At first the organisms and extracts were evaporated down slowly and then dried in an oven at $80 \mathrm{C}$. However, this process of heating was soon abandoned because the residue often underwent changes in color, and the extracts after such heating would go into their respective solvents only with difficulty. So the vacuum desiccator was resorted to and the residue and extracts were dried over $\mathrm{P}_{2} \mathrm{O}_{5}$ in a partial vacuum to constant weights. In all instances the procedures were strictly quantitative.

Table 1 gives the medium, residue, ether and acetone extracts and the percentage of total extractives as obtained by dividing the sum of

TABLE 1

Percentage of Extracts for Various Organisms When Grown in Different Mediums

\begin{tabular}{|c|c|c|c|c|c|}
\hline Organism & Medium & $\begin{array}{c}\text { Acetone } \\
\text { Extract } \\
\text { in Grams }\end{array}$ & $\begin{array}{c}\text { Fther } \\
\text { Extract } \\
\text { in Grams }\end{array}$ & $\begin{array}{l}\text { Residue } \\
\text { in } \\
\text { Grams }\end{array}$ & $\begin{array}{l}\text { Pereentage } \\
\text { of Total } \\
\text { Extracts }\end{array}$ \\
\hline $\begin{array}{l}\text { Bacillus coli } \\
\text { communis }\end{array}$ & $\begin{array}{l}\text { Plain broth............ } \\
1 / 2 \% \text { dextrose broth..... } \\
3 \% \text { glycerol broth....... }\end{array}$ & $\begin{array}{l}0.3523 \\
0.6325 \\
1.9642\end{array}$ & $\begin{array}{l}0.0680 \\
0.042 \\
0.050\end{array}$ & $\begin{array}{c}4.3791 \\
7.419 \\
10.1046\end{array}$ & $\begin{array}{c}9.59 \\
9.09 \\
19.9\end{array}$ \\
\hline $\begin{array}{c}\text { Staphylococcus } \\
\text { albus }\end{array}$ & $\begin{array}{l}\text { Plain broth............. } \\
1 / 2 \% \text { dextrose broth...... } \\
3 \% \text { glycerol broth....... }\end{array}$ & $\begin{array}{l}0.1185 \\
0.1074 \\
0.0961\end{array}$ & $\begin{array}{l}0.1775 \\
0.0424 \\
0.1090\end{array}$ & $\begin{array}{l}3.712 \\
1.968 \\
0.5136\end{array}$ & $\begin{array}{l}7.97 \\
7.6 \\
39.9\end{array}$ \\
\hline $\begin{array}{c}\text { Bacillus } \\
\text { megatheriom }\end{array}$ & $\begin{array}{l}\text { Plain broth.............. } \\
1 \% \% \text { dextrose broth..... } \\
3 \% \text { glycerol broth....... }\end{array}$ & $\begin{array}{l}0.0915 \\
0.0635 \\
0.3755\end{array}$ & $\begin{array}{l}0.0483 \\
0.0372 \\
0.1820\end{array}$ & $\begin{array}{l}1.297 \\
0.559 \\
1.649\end{array}$ & $\begin{array}{l}9.15 \\
18.1 \\
33.8\end{array}$ \\
\hline $\begin{array}{l}\text { Bacillus } \\
\text { mucosus }\end{array}$ & $\begin{array}{l}\text { Plain broth.............. } \\
1 / 2 \% \text { dextrose broth..... } \\
3 \% \text { glycerol broth....... }\end{array}$ & $\begin{array}{l}0.4447 \\
0.6735 \\
1.349\end{array}$ & $\begin{array}{l}0.009 \\
0.0114 \\
0.0140\end{array}$ & $\begin{array}{l}3.269 \\
7.762 \\
8.839\end{array}$ & $\begin{array}{c}13.9 \\
8.82 \\
15.42\end{array}$ \\
\hline
\end{tabular}

the ether and acetone extracts by the residue. Acetone, because of its dehydrating properties, was used as the first solvent. It is true that acetone is a solvent for things other than fats and fatty acids, but we think it safe to assume that the amount of material other than fats weighed in each case will be in proportion to those weighed in any other case. None of the acetone or ether extractives from organisms grown on $0.5 \%$ dextrose broth gave any reduction on addition of Fehling's solution, so little if any sugar was extracted in any case. The ether was used mainly to preclude any possibility of having left any of the fat in the organism by acetone extraction.

From table 1 it appears that the percentage of extracts varies considerably for each organism when grown in different mediums. However, if we consider the biologic action of each organism on the 
different mediums we will find a definite relationship. The colon bacillus has approximately the same percentage of extracts when grown on plain broth as on $0.5 \%$ dextrose broth, but has $100 \%$ more extracts when grown on $3 \%$ glycerol broth. The staphylococcus albus extracts approximate one another on plain broth and $0.5 \%$ dextrose broth but increase $500 \%$ on $3 \%$ glycerol. It will be recalled that both of these organisms ferment dextrose readily but do not ferment glycerol. The B. megatherium, which does not ferment either dextrose or glycerol, increases twofold in percentage of extracts when grown on $0.5 \%$ dextrose and fourfold when grown on $3 \%$ glycerol broth, as compared with plain broth. B. mucosus, which ferments both dextrose and glycerol readily, gives less extracts when grown on dextrose, and approximately the same amount on glycerol as on plain broth. It would seem, therefore, that the percentage of acetone and ether extracts will depend on whether or not the sugar or glycerol in the medium is fermented.

TABLE 2

Results of Growth of B. Coli-COMMUNis and B. COLi-communior on $1 \%$ Saccharose Broth

\begin{tabular}{|c|c|c|c|c|}
\hline Organism & $\begin{array}{c}\text { Acetone } \\
\text { Extract } \\
\text { in Grams }\end{array}$ & $\begin{array}{c}\text { Ether } \\
\text { Extract } \\
\text { in Grams }\end{array}$ & $\begin{array}{l}\text { Residue } \\
\text { in } \\
\text { Grams }\end{array}$ & $\begin{array}{c}\text { Percentage } \\
\text { Extrac- } \\
\text { tive }\end{array}$ \\
\hline $\begin{array}{l}\text { Bacillus coli-eommunior } \ldots \ldots \ldots \ldots \ldots \ldots \ldots \ldots \\
\text { Bacillus coli-communis } . . \ldots \ldots \ldots \ldots \ldots \ldots \ldots\end{array}$ & $\begin{array}{l}0.5033 \\
0.7813\end{array}$ & $\begin{array}{l}0.0030 \\
0.0125\end{array}$ & $\begin{array}{l}5.885 \\
6.148\end{array}$ & $\begin{array}{r}8.60 \\
12.91\end{array}$ \\
\hline
\end{tabular}

In order to study this point further pure strains of B. coli-communis and $\mathrm{B}$. coli-communior were grown on $1 \%$ saccharose broth. The former does not ferment saccharose while the latter does. Table 2 gives the results obtained.

B. coli-communis, which gives $12.66 \%$ extractives, does not ferment the sugar but apparently metabolizes it into fat, while B. coli-communior does ferment the sugar, and the total extract is about $33 \%$ less.

In order to rule out the possibility of the acetone taking out material other than fats which would account for the results obtained, the acetone extracts from Staphylococcus albus, B. mucosus grown on plain broth, dextrose broth and glycerol broth, respectively, and B. colicommunis and B. coli-communior grown on $1 \%$ saccharose broth were reextracted with redistilled petroleum ether. The extracts of the other organisms were not so treated as they were not kept quantitatively and therefore would not give quantitative results. Petroleum ether will dissolve out the neutral fats and fatty acids. Table 3 gives the results. 
A comparison of the total petroleum ether and ether extracts with the total acetone and ordinary ether extracts shows a proportionate reduction in each case. The petrol ether extracts represent more nearly the true fats or fatlike content of the organisms; the results are changed only in amount and not in proportion. Even though the other extracts were omitted in each case, the petrol ether extracts would give percentages in the same proportions as the figures given in table 3 . Neither glycerol nor dextrose is soluble in petroleum ether so the results obtained are not due to the dissolving out of glycerol or dextrose from the medium.

Cramer's ${ }^{1}$ work gives a $100 \%$ increase in ether and alcohol extractives for both B. mucosus and bacillus of rhinoscleroma when grown on

TABLE 3

Results of Reextracting and Redistulting Acetone Extracts from Staphylococcus Aleus, B. mucoccus Grown on Plain Broth, Dextrose Broth and Glycerol Broth

\begin{tabular}{|c|c|c|c|c|c|c|}
\hline Organjsm & Medium & $\begin{array}{c}\text { Petroleum } \\
\text { Ether } \\
\text { Extract } \\
\text { in } \\
\text { Grams }\end{array}$ & $\begin{array}{c}\text { Ether } \\
\text { Extruct } \\
\text { in Grans }\end{array}$ & $\begin{array}{l}\text { Residue } \\
\text { in } \\
\text { Grams }\end{array}$ & $\begin{array}{l}\text { Percentage } \\
\text { of Total } \\
\text { Ether } \\
\text { Extracts }\end{array}$ & $\begin{array}{l}\text { Percentage } \\
\text { of Total } \\
\text { Acetone } \\
\text { and Ether } \\
\text { Extracts } \\
\text { (From } \\
\text { Table 1) }\end{array}$ \\
\hline $\begin{array}{l}\text { Staphylococeus } \\
\text { albus }\end{array}$ & $\begin{array}{l}\text { Plain broth........ } \\
1 / \% \% \text { dextrose brotr } \\
3 \% \text { glycerol broth. }\end{array}$ & $\begin{array}{l}0.0381 \\
0.0177 \\
0.0858\end{array}$ & $\begin{array}{l}0.1775 \\
0.0424 \\
0.1090\end{array}$ & $\begin{array}{l}3.712 \\
1.968 \\
0.5136\end{array}$ & $\begin{array}{r}5.68 \\
3.06 \\
28.19\end{array}$ & $\begin{array}{l}7.97 \\
7.6 \\
39.9\end{array}$ \\
\hline $\begin{array}{l}\text { Bacillus } \\
\text { mucosus }\end{array}$ & $\begin{array}{l}\text { Plain broth....... } \\
1 / 2 \% \text { dextrose brotl } \\
3 \% \text { glycerol broth.. }\end{array}$ & $\begin{array}{l}0.1875 \\
0.2386 \\
0.2956\end{array}$ & $\begin{array}{l}0.009 \\
0.0114 \\
0.0140\end{array}$ & $\begin{array}{l}3.263 \\
7.7 f 9 \\
8.839\end{array}$ & $\begin{array}{l}6.02 \\
3.22 \\
3.52\end{array}$ & $\begin{array}{c}13.9 \\
8.82 \\
15.4 ?\end{array}$ \\
\hline $\begin{array}{l}\text { B. coli- } \\
\text { communis }\end{array}$ & $1 \%$ saccharose broti & 0.406 & 0.0125 & 6.148 & 6.80 & $\begin{array}{l}19.91 \\
\text { Table } 2\end{array}$ \\
\hline $\begin{array}{l}\text { B. colf- } \\
\text { communior }\end{array}$ & $1 \%$ saccharose broth & $0.23 \% 8$ & 0.003 & 5.885 & 4.09 & $\begin{array}{c}8.60 \\
\text { Table } 2\end{array}$ \\
\hline
\end{tabular}

$5 \%$ dextrose as compared with $1 \%$ peptone. This is in contrast with the results herein recorded in the case of $B$ : mucosus, in which it was found that the fat content did not increase on addition of carbohydrate to the medium. His results with the bacillus of rhinoscleroma, however, agree with our work since this organism does not ferment dextrose, and it would be expected that the fat content would increase when the organism is grown on this particular carbohydrate.

The work of Frouin may be cited here in support of our theory. The human strain of B. tuberculosis ferments glycerol, as shown by Theobald Smith, ${ }^{15}$ while the bovine and avian strains do not. Frouin's

15 Jour. Med. Research, 1904, 8, p. 253. 
figures show from 42 to $45 \%$ fats for the bovine and $40 \%$ for the avian strains, but only $19.59 \%$ for the human strain. It would be interesting to know whether or not the one particular bovine strain in which he obtained approximately the same amount of fat $(20 \%)$ as with the human strain, was a glycerol fermenter. Apparently the fat content of the tubercle bacillus grown on glycerol mediums does not depend on its virulence but rather on whether or not the glycerol is fermented.

Table 1 shows that B. coli, B. megatherium and Staph. albus, when grown on $3 \%$ glycerol, have a fat content approximating that of the tubercle bacillus. This naturally raises the question whether those organisms high in fat content are necessarily acid-fast. Investigation of this point revealed that their staining properties were not changed by the increased fat content. Therefore, the tubercle bacillus probably

TABLE 4

Results of Growth of Organisms on Plain Beef Broth, Dextrose Broth and 3\% Glycerol Broth

\begin{tabular}{|c|c|c|c|}
\hline & Plain Broth & $1 / 2 \%$ Dextrose & $3 \%$ Glycerol \\
\hline 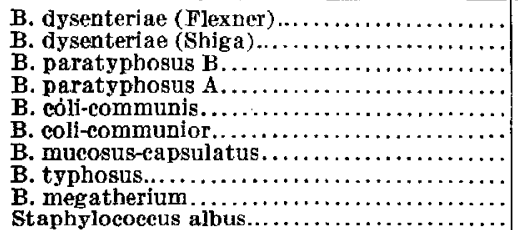 & $\begin{array}{l}\bar{z} \\
\bar{z} \\
\overline{\bar{P}} \\
\frac{\bar{P}}{?}\end{array}$ & $\begin{array}{l}=(f) \\
=(f) \\
=(f) \\
=(f) \\
=(f) \\
P(f) \\
-(f) \\
?(f) \\
?(f)\end{array}$ & $\begin{array}{l}\mathbf{P} \\
\stackrel{?}{\mathbf{P}} \\
\stackrel{\mathbf{P}}{\mathbf{P}} \\
\stackrel{\mathbf{P}}{\mathbf{P}} \\
\stackrel{\mathbf{P}}{\mathbf{P}} \\
\stackrel{\mathbf{P}}{\mathbf{P}}\end{array}$ \\
\hline
\end{tabular}

$\mathbf{P}=$ Pellicle formation; $?=$ ring formation; $-=$ no pellicle $;(t)=$ ferments medium; (ti) $P=$ questionable fermentation.

does not owe its acid-fastness to its high fat content but rather to the character of the fats or other substances present.

In order to investigate further the theory on which this work was begun, namely, that the lack of wetting of organisms was due, in part, to an increase in their fat content, a series of organisms was grown on plain beef broth, $0.5 \%$ dextrose broth and $3 \%$ glycerol broth, respectively. Pure strains of B. coli, B. typhosus, B. paratyphosus A and B, B. megatherium, B. dysenteriae, B. mucostus and the Staph. albus were used (table 4).

B. mucosus forms a pellicle on all the mediums while none of the others form pellicles on plain broth or on $0.5 \%$ dextrose broth. However, on $3 \%$ glycerol broth they all form pellicles. From our studies on fat content we should predict that all the organisms of this series should have a high fat content when grown on $3 \%$ glycerol, with the 
exception of the B. mucosus, since they do not ferment glycerol. If pellicle formation is a phenomenon of wetting, the lack of wetting, due to increased fat content of the organism when grown on certain mediums, might explain this phenomenon. That other factors such as the surface tension of the medium and inherent qualities of the bacteria themselves, undoubtedly enter into the causes of pellicle formation is conceded, because organisms such as B. mucosus form pellicles in spite of relatively low fat content, but the results we obtained would indicate that fat content of the organism is an important factor. The character of the fat present or the disposition of the fat in the organism may be the determining factor.

\section{SUMMARY}

Earlier workers have confined their investigations on the fat content of bacteria largely to the tubercle bacillus.

The results herein recorded seem to establish the general law that carbohydrates and glycerol are converted into fats or fatlike substances only when they are not fermented by the organisms.

The fat content of the tubercle bacillus bears no relation to the virulence of the organism but is determined by its biologic action on the glycerol in the medium.

The acid-fast staining properties of the tubercle bacillus are not due to its high fat content but probably to the character of the fats or other substances present.

Pellicle formation by bacteria is probably determined by the surface tension of the medium on the one hand and the fat content of the organisms on the other.

The methods of fat extraction used may have taken out substances other than fats or may not have extracted all the fats, but the results are comparable. In this paper we have called the extracts fats. Since there is no accepted criterion as to what a fat is, the term is used in its broadest sense. 